\title{
Employee Equity, Incentive Compensation, and Growth in Entrepreneurial Firms
}

\author{
J. B. Arbaugh \\ Larry W. Cox \\ S. Michael Camp
}

$W$

Te examined the relationship between employee equity compensation, incentive compensation, and firm growth using a sample of 480 privately held firms from the Ewing Marion Kauffman Foundation's database of Ernst \& Young Entrepreneur Of The Year (EOY) winners. Using frameworks from agency and motivation theories, we argued that larger percentages of both equity- and incentivebased compensation allocated to top managers and employees would be associated with firm growth. After controlling for firm and industry effects, the results of the study showed that while the firms in the sample preferred providing incentive compensation, providing equity compensation for employees was a positively significant predictor of firm growth over a three-year period. These findings suggest that prescriptions for growth in larger firms developed from agency theory also may be applicable to entrepreneurial firms, and founder/CEOs seeking to grow their firms should consider using equity compensation to motivate their current employees and to attract new ones.

While financing growth has long been an area of intrigue in entrepreneurship research (Brophy 1997; Mason and Hamilton 2000), compensation of the employees who assist the entrepreneur in achieving this growth remains a virtually unresearched field (Heneman, Tansky, and Camp 2000). In one of the original studies of the successful management of rapid growth, Hambrick and Crozier (1985) found that successfully growing firms provided their employees with some sort of stake in the outcome of the firm. However, this study was done before offering stock or stock options to people in levels below senior management became commonplace (Kambil, Eselius, and Monteiro 2000), and most of the research in equity-based compensation has continued to focus on senior managers in relatively large firms (Rajagopalan 1997; Zahra, Neubaum, and Huse 2000).

Research in equity and incentive compensation issues is relevant for entrepreneurial firms for several reasons. First, funding in entrepreneurship research has historically focused on venture capital financing (Amit, Brander, and Zott 2000). However, most entrepreneurial firms do not seek venture capital (Bhide 1992; Brophy, 1997). This suggests that these firms are obtaining financing by other means, but as of yet it is not clear how those alternative financing arrangements are structured (Mason and Hamilton 2000). Since most growth-oriented firms are privately held companies, the study of the role of equitybased compensation, incentive compensation, and firm growth has been somewhat limited. Secondly, recruitment and retention of talent is critical for entrepreneurial firms (Brush, Greene, and Hart 2001). Determining whether equity positions, incentive compensation, or a combination of these approaches is most appropriate would greatly assist entrepreneurs in their efforts to recruit and retain top performers for their firms. Lastly, employee motivation both to stay and to perform is important for the entrepreneurial firm to manage costs, stabilize the organization, and provide organizational legitimacy (Cooper and Folta 2000; Greiner 1998; Reynolds 1987). These observations raise several questions pertaining to equity and incentive compensation in the entrepreneurial firm. Some of these questions include: What is the relationship between ownership, incentive compensation and firm growth? Is equity- or incentive-based compensation a better predictor of firm growth? How is ownership and incentive compensation distributed among entrepreneurial firms? In this article we report the results of a study suggesting that while the leadership of entrepreneurial firms may have a preference for providing incentive compensation, equity compensation may in fact be more strongly associated with firm growth.

The remainder of this article is divided into four sections. First, we will review some literature on ownership allocations within an agency framework and use this literature to develop hypotheses of firm ownership allocations and growth in entrepreneurial firms. Next, we review literature on incentive compensation and trace its roots in motivation theory. From this discussion, we develop hypotheses of incentive compensation and firm growth. The next section describes the results of the tests of these hypotheses using a sample of privately held entrepreneurial firms from the Ewing Marion Kauffman Foundation's database of Ernst \& Young Entrepreneur Of The Year (EOY) winners. The article concludes with a discussion of 
the findings and some potential implications for both managers and researchers on employee incentives and growth in entrepreneurial firms.

\section{Agency Theory and Ownership in Entrepreneurial Firms}

Ownership issues in growth-oriented firms have not received significant research attention, largely because it has been an implicit assumption that the founder/CEO and/or their family members control most if not all of the firm's equity (Kelly and Hay 2000; Markman, Balkin, and Schjoedt 2001). Historically, research of ownership positions and firm performance have focused on publicly held firms and those about to go public via an IPO (Certo et al. 2003; Dalton et al. 2003). Therefore, ownership-performance relationships in privately held or closely held growth-oriented firms have not been a focus of this research stream. While this is likely the case with lifestyle firms (Bento and White 2001), the literature on teams and IPOs suggest that this assumption may not be accurate when considering the growth-oriented firm. Since the strategies, organization structures, and perceptions of growth-oriented firms are more likely to resemble those of firms undergoing IPOs than those of lifestyle firms (Cooper and Daily 1997; Sexton and Bowman-Upton 1991; Siegel, Siegel, and MacMillan 1993), these literatures may be a good source of information for theorizing about ownership structures in entrepreneurial firms.

One of the most prominent characteristics associated with successfully seeking outside funding is the quality of a firm's management team (Birley and Stockley 2000; MacMillan, Siegel, and SubbaNarashima 1985). Indeed, the idea that a management team rather than a single entrepreneur typically promotes firm growth is common in the entrepreneurship literature (Cooper and Bruno 1977; Cooper and Daily 1997; Eisenhardt and Schoonhoven 1990), and recent research suggests that an owner-controlled privately held firm with multiple management layers is more efficient than an owner-controlled firm with a flat organizational structure or an agent-led firm of either management structure (Durand and Vargas 2003). Some reasons for this thinking are the ability to exert greater effort, reduced reliance on a single person, complementary skills and knowledge, the lead entrepreneur's ability to attract and manage people, and/or as an initial check of the soundness of the venture idea (Cooper and Daily 1997; Vesper 1990).

Therefore, if the caliber of the management team is a significant factor in firm growth, what is the most effective way to keep a good team together? Insights from agency theory provide some useful ideas. While agency theory has typically been used to explain behavior and ownership structures in large firms (Barkema and Gomez-Mejia 1998; Fama and Jensen 1983; Jensen and Meckling 1976; Stroh 1996), its use is becoming more common in research of smaller and privately held firms (Durand and Vargas 2003; Zahra et al. 2000) and researchers have recently called for additional study of principal-agent relationships in entrepreneurial settings (Manigart and Sapienza 2000).

In the context of entrepreneurship research, principalagent issues are particularly relevant when studying growing firms with a lead entrepreneur as CEO (Hitt, Ireland, and Hoskisson 2001). One of the primary challenges of the entrepreneur of the growth-oriented firm is to establish organizational legitimacy (Deephouse 1996; Lounsbury and Glynn 2001). One way to gain legitimacy is to build a balanced team of professionals with industry experience (Hambrick and Crozier 1985; Siegel et al. 1993). Attracting and retaining talent has always been a challenge for growth-oriented firms (Fombrun and Wally 1989; Hambrick and Crozier 1985; Heneman et al. 2000). This suggests that talented managers and employees in growth-oriented firms further develop their relatively unique set of talents and abilities (Castanias and Helfat 2001) and are seen as attractive assets to the firm. As a result, the entrepreneur must seek ways to limit managerial opportunism (Moran and Ghoshal 1996; Williamson 1993), which in this context would likely mean that the manager might leverage his or her firm knowledge and/or position to gain a position with another firm or even start his or her own firm (Autio 2000; Cooper and Folta 2000). A possible solution to this problem may be to reduce the tensions inherent in the principal-agent relationship by providing ownership opportunities to the firm's managers, and by extension to its employees (Case 1995; Himmelberg, Hubbard, and Palia 1999). Equity-based compensation has been used to promote entrepreneurial behavior in larger firms (Block and Ornati 1987; Ireland, Kuratko, and Hornsby 2001; Sykes 1992). In addition to making it easier to attract executive and professional level talent (Hambrick and Crozier 1985), this approach also could be attractive to the owners of the growth-oriented firm because it would be comparatively inexpensive to monitor, thereby reducing agency costs (Banker et al. 1996) which is important since cash is typically scarce in growth-oriented firms (Reynolds 1987). These points are reflected in the following hypothesis:

H1: Equity ownership by employees will be positively associated with growth in entrepreneurial firms. 


\section{Incentive Compensation and Motivation Theory in Entrepreneurial Firms}

While broadening ownership may reduce agency costs and encourage employees to think like owners, many entrepreneurs find the thought of relinquishing control of their firm unattractive (Cable and Shane 1997; Greenberger and Sexton 1988; Kelly and Hay 2000; Markman et al. 2001). Therefore, entrepreneurs may prefer to try to motivate the employees of the firm through nonequity-based incentive compensation (bonuses, profit sharing, etc). The rationale for incentive compensation is rooted in the expectancy theory of motivation (Vroom 1964). According to expectancy theory, motivation will be high when employees believe that their efforts will lead to high performance (expectancy), and that high performance will result in the attainment of particular outcomes (instrumentality) and these outcomes are desired by the employees (valence). The idea of incentive compensation is based on the assumption that the opportunity for increased compensation or benefits will motivate employees to raise or maintain their efforts to perform at a high level.

Like many areas of human resources research in smaller firms, incentive compensation is a relatively neglected topic (Heneman et al. 2000; Katz et al. 2000). This is because research on the relationship between pay and firm growth has again typically focused on senior management in relatively large firms (Balkin and Gomez-Mejia 1987; 1990; Barkema 1996; Boyd and Salamin 2001; Rajagopalan 1997). This research suggests that incentive pay is commonly used by firms that wish to encourage the identification and pursuit of growth opportunities (Balkin and Gomez-Mejia 1990; Boyd and Salamin 2001) and may be more of a motivator for pursuing growth strategies than equity-based compensation (Barkema 1996). A possible explanation for this is that employees may feel that receiving rewards from incentive-based compensation is less risky than equity-based compensation in the growing firm (Beatty and Zajac 1994).

In studies of nonsenior employees, incentive compensation has been found to be associated with lower turnover, higher productivity, and enhanced performance in larger firms, especially when combined with training (Delaney and Huselid 1996). These findings are also somewhat supported by the few studies of incentive compensation in smaller firms. Welbourne and Andrews (1996) found that incentive compensation programs were negatively associated with IPO stock prices, but positively associated with five-year survival rates. Chandler and McEvoy (2000) found that incentive compensation did not predict firm profitability but was a moderator of TQM implementation effectiveness. Collectively, this literature suggests the following hypothesis:

\section{H2: Incentive compensation for employees will be positively associated with growth in entre- preneurial firms.}

\section{Methods}

\section{Background}

Entrepreneurship research has historically been hindered because of the relative lack of large, robust databases containing financial performance data for entrepreneurial ventures (Landstrom and Sexton 2000). This is largely due to the fact that these firms are typically privately held and therefore not required to release financial information. To help address this difficulty, the Ewing Marion Kauffman Foundation has devoted substantial time and money to the development of large sample databases that include financial data for entrepreneurial firms. Because of these efforts, the 1998 Ernst \& Young Entrepreneur Of The Year Institute (EOYI) database, codeveloped by the Ewing Marion Kauffman Foundation and Ernst \& Young, is used for the sample for this study. The firms in this database were finalists in the Ernst \& Young Entrepreneur Of The Year award competition. EOYI members are CEOs (primarily founders) from arguably the most innovative and admired firms in the world. They represent the "best of the best" in terms of their contribution to growth, profitability, job creation, and economic impact.

Specific details of the development of the EOYI database have been described by Cox, Ensley, and Camp (2003). The EOYI database contains information on ownership structure, compensation policies, human resource practices, and performance on 596 firms. These firms averaged $\$ 100$ million in sales during 1997, ranging from less than $\$ 1$ million to more than $\$ 7$ billion. Average annual sales growth rates for the sample ranged from less than 5 percent to more than 110 percent. The database is comprised primarily of firms in the manufacturing, service, and wholesale trades. When compared to the Longitudinal Establishment and Enterprise Microdata database maintained by the U.S. Bureau of the Census, the EOY database contains comparatively larger firms, but is fairly representative of the distribution of firms in the United States. Considering that the database consists of firms considered to be outstanding, the size and performance differences between them and the general population should not be surprising. This study focused on the 480 privately held firms in the database. 


\section{Measures}

Dependent Variables. It has been argued that profitability-based measures may not be appropriate measures for privately held firm performance because owners may shift business profit and personal income in ways to minimize their total tax liability (Hulse and Pope 1996). Also, while profitability-based measures of performance work well for larger firms with older assets in place, they are influenced by historical costs and may not capture the value of younger firms since smaller firms comprise a disproportionate number of new ventures (Keasey and Watson 1993; Smith and Watts 1992). Conversely, there is a substantial history of using variables such as growth in sales and/or employees as a performance measure in studies of privately held, growth-oriented firms due in part to the fact that these variables are not subject to the age- and tax-related limitations of profitability-related measures (Davidsson and Wicklund 2000). Therefore, sales and employee growth from 1995 through 1998 were used as the dependent variables in this study (Baum, Locke, and Smith 2001; Bento and White 2001). Three- to five-year time periods as measures of performance and/or growth have often been used in previous entrepreneurship research (Brush and VanderWerf 1992; Davidsson 1991; Robinson and McDougall 1998).

Predictor Variables. Since approximately 55 percent (260 of 480) of the firms in the sample had no employees who owned any equity in their respective firm, we created a dummy variable where: 1 = some equity ownership by employees and $0=$ no equity ownership by employees. Since almost 99 percent (475 of 480) of the firms in the sample offered some sort of incentive compensation to their employees, we measured incentive compensation as the percentage of the firm's total incentive compensation allocated to the firm's top managers and all other employees respectively.

Control Variables. To account for conditions at the beginning of the study period, firm age in 1999 (Chandler and Hanks 1994; Kazanjian and Drazin 1990) and the amount of 1995 sales and the number of employees in 1995 were included as control variables (Davidsson and Wicklund 2000). To control for potential leadership changes, we measured CEO tenure as the number of years the CEO had held the position. We also used several firmand industry level variables, measuring them as a percentage of total firm sales. We used total compensation expense to control for varying degrees of labor intensiveness v. capital intensiveness across both firm and industry settings. We included the firm's international sales since internationalization has been shown to be a predictor of sales growth in small and/or privately held firms
(Bloodgood, Sapienza, and Almedia 1996; Burgel, Fier, Licht, and Murray 2000). For industry-level effects, we used R\&D expense and sales and marketing expense to control for the relative importance of basic research and promotional intensity across industries (Dowling and McGee 1994; Mizik and Jacobson 2003).

\section{Results}

Table 1 provides the descriptive statistics for the variables in this study. It shows that the firms in the sample experienced substantial growth in sales during the study period. On average, sales and employees increased by 76 and 66 percent, respectively, from 1995 to 1998. Most of the firms' incentive compensation goes to top managers (47.49\%), with all other employees receiving 30.36 percent of total incentive compensation. While there are several statistically significant correlations, there are only 15 that are greater than .3 , and almost all of these are between the dependent variables and/or the control variables.

Table 2 reports the results of regressions of the control and predictor variables on sales and employee growth. We will use this information to test our hypotheses. Hypothesis 1 predicted that equity compensation would be associated with firm growth. This hypothesis is supported. Equity compensation given to employees was a significantly positive predictor of both sales and employee growth $(\mathrm{p}<.1)$. Hypothesis 2 predicted that incentive compensation for employees would be associated with firm growth. None of the measures of incentive compensation were significantly associated with either sales or employee growth. Therefore, this hypothesis was not supported. Of the control variables, the number of employees $(\mathrm{p}<.001)$ at the start of the study period positively predicted both measures of growth, while CEO tenure negatively predicted both measures of growth $(\mathrm{p}<.05$ for sales, $\mathrm{p}<.1$ for employees). Sales at the beginning of the period predicted sales growth $(\mathrm{p}<.001)$. Interestingly, total compensation expense was a negative predictor of sales growth $(p<.05)$ but positively predicted employee growth $(\mathrm{p}<.01)$. Firm age $(\mathrm{p}<.001)$ and internationalization $(\mathrm{p}<.1)$ were negative predictors of sales growth.

\section{Discussion}

This study has helped address recent calls for further investigation of agency effects in smaller and/or privately held firms (Durand and Vargas 2003; Manigart and Sapienza 2000; Zahra et al. 2000). Using our sample of entrepreneurial firms, we found that $\mathrm{CEO} /$ entrepreneurs prefer to provide incentive compensation rather than equi- 
Table 1

Descriptive Statistics of the Variables in the Study $(n=480)$

\begin{tabular}{|c|c|c|c|c|c|c|c|c|c|}
\hline & Mean & S. D. & 1 & 2 & 3 & 4 & 5 & 6 & 7 \\
\hline 1. Sales Growth & 16632221.87 & 23360201.92 & 1.00 & & & & & & \\
\hline 2. Employee Growth & 77.75 & 138.26 & .42 & 1.00 & & & & & \\
\hline 3. Firm Age & 19.38 & 19.01 & .02 & .01 & 1.00 & & & & \\
\hline 4. Employees in 1995 & 117.80 & 155.86 & .36 & .51 & .34 & 1.00 & & & \\
\hline 5. Firm Sales in 1995 & 21912153.01 & 25545222.28 & .40 & .32 & .39 & .64 & 1.00 & & \\
\hline 6. CEO Tenure & 95.48 & 73.68 & .04 & .06 & .43 & .38 & .39 & 1.00 & \\
\hline $\begin{array}{l}\text { 7. International Sales/Total } \\
\text { Sales }\end{array}$ & 7.27 & 15.64 & -.09 & -.07 & -.05 & -.02 & -.07 & -.01 & 1.00 \\
\hline $\begin{array}{l}\text { 8. Total Compensation } \\
\text { Expense/Total Sales }\end{array}$ & 34.06 & 22.34 & -.13 & .08 & -.19 & -.08 & -.23 & -.17 & .08 \\
\hline 9. $\mathrm{R}$ and D Expense/Total Sales & 6.49 & 9.95 & .09 & -.10 & -.23 & -.19 & -.20 & -.24 & .30 \\
\hline $\begin{array}{c}\text { 10. Sales and Marketing } \\
\text { Expense/Total Sales }\end{array}$ & 18.06 & 22.61 & -.03 & -.02 & -.08 & -.08 & -.04 & -.11 & .10 \\
\hline $\begin{array}{l}\text { 11. Firms Offering Employee } \\
\text { Equity Compensation }\end{array}$ & 0.46 & 0.50 & .09 & .11 & -.14 & -.01 & -.01 & -.27 & .12 \\
\hline $\begin{array}{l}\text { 12. Top Manager } \\
\text { Incentives/Total Incentive } \\
\text { Compensation }\end{array}$ & 47.49 & 22.20 & -.02 & -.01 & .03 & .05 & .07 & .03 & .02 \\
\hline $\begin{array}{l}\text { 13. Other Employee } \\
\text { Incentives/Total Incentive } \\
\text { Compensation }\end{array}$ & 30.36 & 27.46 & .04 & .08 & .01 & .06 & .01 & -.02 & .03 \\
\hline
\end{tabular}

\begin{tabular}{|c|c|c|c|c|c|c|c|}
\hline & Mean & S. D. & 8 & 9 & 10 & 11 & 12 \\
\hline $\begin{array}{l}\text { 8. Total Compensation } \\
\text { Expense/Total Sales }\end{array}$ & 34.06 & 22.34 & 1.00 & & & & \\
\hline 9. $\mathrm{R}$ and D Expense/Total Sales & 6.49 & 9.95 & 43 & 1.00 & & & \\
\hline $\begin{array}{l}\text { 10. Sales and Marketing } \\
\text { Expense/Total Sales }\end{array}$ & 18.06 & 22.61 & 17 & .33 & 1.00 & & \\
\hline $\begin{array}{l}\text { 11. Firms Offering Employee } \\
\text { Equity }\end{array}$ & 0.46 & 0.50 & .17 & .24 & .06 & 1.00 & \\
\hline $\begin{array}{l}\text { 12. Top Manager } \\
\text { Incentives/Total Incentive } \\
\text { Compensation }\end{array}$ & 47.49 & 22.20 & -.03 & .05 & .15 & .02 & 1.00 \\
\hline $\begin{array}{l}\text { 13. Other Employee } \\
\text { Incentives/Total Incentive } \\
\text { Compensation }\end{array}$ & 30.36 & 27.46 & .03 & .01 & -.07 & .05 & -.49 \\
\hline
\end{tabular}

Note: Correlations above .09 are significant at the $\mathrm{p}<.05$ level; correlations above .11 are significant at the $\mathrm{p}<.01$ level

ty compensation for senior management and other employees. However, only equity-based compensation was significantly associated with firm growth. This finding suggests that $\mathrm{CEO} /$ entrepreneurs may be maintaining control of their firms at the price of sustained growth, and by extension, reducing their opportunities to create wealth. We will now provide some possible explanations for our findings.

One possible explanation is the relative age of firms in the sample. The average age was just over 19 years. So while they were not new ventures (Brush and VanderWerf 1992; Robinson 1999), their equity and compensation pat- 
Table 2

Results of Regression Analyses on Sales and Employee Growth

\begin{tabular}{|c|c|c|}
\hline & Sales Growth & $\begin{array}{l}\text { Employee } \\
\text { Growth }\end{array}$ \\
\hline Intercept & $17698830.24 * * *$ & 19.07 \\
\hline Firm Age & $-186087.72 * * *$ & -1.15 \\
\hline Employees in 1995 & $34183.08 * * *$ & $.47 * * *$ \\
\hline Firm Sales in 1995 & $.30 * * *$ & .00 \\
\hline CEO Tenure & $-251950.63 *$ & $-1.30+$ \\
\hline International Sales/Total Sales & $-103079.69+$ & -.46 \\
\hline Total Compensation Expense/Total Sales & $-98481.34 *$ & $.81 * *$ \\
\hline $\mathrm{R}$ and D Expense/Total Sales & -1395.61 & $-1.52 *$ \\
\hline Sales and Marketing Expense/Total Sales & 7217.91 & .14 \\
\hline $\begin{array}{l}\text { Firms Offering Employee Equity } \\
\text { Compensation }\end{array}$ & $3600267.99+$ & $20.91+$ \\
\hline $\begin{array}{l}\text { Top Manager Incentives/Total Incentive } \\
\text { Compensation }\end{array}$ & -54391.77 & -.04 \\
\hline $\begin{array}{l}\text { Other Employee Incentives/Total Incentive } \\
\text { Compensation }\end{array}$ & -6112.17 & .22 \\
\hline $\mathrm{F}$ & $12.89 * * *$ & $20.49 * * *$ \\
\hline d.f. & 11,468 & 11,468 \\
\hline Adjusted R-squared & .21 & .31 \\
\hline
\end{tabular}

Note: $+\mathrm{p}<.1$

$* \quad \mathrm{p}<.05$

$* * \quad \mathrm{p}<.01$

$* * * \mathrm{p}<.001$

terns may still be reflective of conditions at the start of the business (Boeker 1989; Brush and Chaganti 1998). Because of this still relatively young age, these firms may not have experienced the organizational crises where others in the organization beyond the founder/CEO need to be given more ownership for the firm to continue to survive and grow (Greiner 1998). However, the age of the firms in the sample does suggest that these firms were not "born to go public," which may indicate that the firms that provide employee equity are not doing it so that employees can cash out their positions in a future public offering.

Resource-based theory may also provide some explanations for these findings. Resource-based theory suggests that firm resources and capabilities are socially complex (Alvarez and Busenitz 2001) and relatively immobile across firms (Barney 2001). If this is the case, the entrepreneur/CEO's concerns about key people leaving the firm are minimized because their skills and knowledge are context-specific. Therefore, these sets of knowledge and skills are both able to be retained by the rebundling of the firm's remaining knowledge, resources, and capabilities and not be directly or completely transferable to other firms (Grant 1996). However, the findings are consistent with recent research of larger firms which suggests that managers who hold equity positions in the firm will place a greater emphasis on internally generated innovation (Hoskisson et al. 2002). Therefore, CEOs may be offering the equity as a means to fuel the firm's innovation and subsequent growth.

Explanations for the nonsignificance of incentive compensation allocations and growth are not as clearly evident. However, a possible explanation might be found in how compensation is perceived in growing firms. While compensation is viewed in monetary terms, there is some 
evidence that benefits such as opportunities to do interesting, meaningful work, learn new information and skills, work with enjoyable and stimulating colleagues, and seek work-life balance are also viewed as compensation by employees of growth-oriented firms (Heneman et al. 2000). Therefore, the opportunity to have a voice in determining the future direction of the firm that an equity position provides may be a reasonable part of a compensation package in such a setting.

These findings certainly counter the contention that founder/CEOs are the sole drivers of growth-oriented firms. Recent research suggests that CEO motivation, technical and industry skills, and strategy selection significantly influence firm growth even when other organizational and environmental characteristics are accounted for (Baum et al. 2001) and that the venture's success hinges largely upon the entrepreneur's ability to the communicate the firm's story in ways that attract resources and credibility to the firm (Lounsbury and Glynn 2001). With that much riding on the entrepreneur's shoulders, it is understandable why he or she may be hesitant to relinquish control of the firm to others (Kelly and Hay 2000). However, by encouraging employees to think like owners through the granting of equity (Case 1995), the entrepreneur may help further develop the people of the firm to take on greater responsibility of the day-to-day operations, thereby allowing him or her to focus more on the firm's longer term strategic direction.

As is the case with all studies, our findings must be interpreted in light of our study's limitations. One limitation is that equity and incentive compensation positions were measured at the end of the study period rather than the beginning, which assumes they stayed the same during the entire period. A second limitation may be related to the nature of the sample. While all firms in the sample were considered by at least some to be outstanding, not all firms in the sample were growing rapidly. This could indicate that the number of firms offering employee equity in this sample may not be representative of the general population. We heartily encourage other researchers to address these concerns in future studies.

\section{Conclusions}

While these limitations certainly provide research opportunities, there also appear to be abundant opportunities for future research in rewards structures in growth-oriented firms. For instance, the fact that the presence of equitybased employee compensation moderately predicted firm performance runs counter to the conclusion of Dalton and colleagues' (2003) recent meta-analysis, which found no relationship between employee equity positions and firm performance. This could suggest that the employee equity-performance relationship is a phenomenon unique to entrepreneurial firms. Another area for further research could be on the role compensation plays in the development of organizational capabilities. While the role of the founder/CEO cannot be denied, at some point the organization needs to develop capabilities beyond those of the CEO if continued growth occurs (Brush et al. 2001). An interesting question might be whether equity or incentive compensation is more effective in encouraging the development of organizational capabilities (Chandler and McEvoy 2000).

Our study shows that equity-based compensation is associated with growth in privately held entrepreneurial firms. Therefore, we find it interesting that what Hambrick and Crozier (1985) found to be true almost 20 years ago about the role of equity compensation and the successful management of growth may still be true today. Founders and/or CEOs of privately held firms that wish to become more entrepreneurial would do well to heed their advice.

\section{References}

Alvarez, S. A., and L. W. Busenitz. 2001. The entrepreneurship of resource-based theory. Journal of Management 27: 755-775.

Amit, R., J. Brander, and C. Zott, C. 2000. Venture capital financing of entrepreneurship: Theory, empirical evidence, and a research agenda. In D. L. Sexton and H. Landstrom, eds., The Blackwell Handbook of Entrepreneurship. Oxford: Blackwell, 259-281.

Autio, E. 2000. Growth of technology-based new firms. In D. L. Sexton and H. Landstrom, eds., The Blackwell Handbook of Entrepreneurship. Oxford: Blackwell, 329-347.

Balkin, D. B., and L. R. Gomez-Mejia. 1987. Toward a contingency theory of compensation strategy. Strategic Management Journal 8: 169-182.

Balkin, D. B., and L. R. Gomez-Mejia. 1990. Matching compensation and organizational strategies. Strategic Management Journal 11: 153-169.

Banker, R. D., S. Lee, G. Potter, and D. Srinivasan. 1996. Contextual analysis of performance impacts of outcome-based incentive compensation. Academy of Management Journal 39: 920-948. 
Barkema, H. G. 1996. The effects of board control and compensation mix on strategic orientation." In B. S. Prasad and B. K. Boyd, eds. Advances in International Comparative Management. Greenwich, CT: JAI Press, 127-141

Barkema, H. G., and L. R. Gomez-Mejia. 1998. Managerial compensation and firm performance: A general research perspective. Academy of Management Journal 41: 135-145.

Barney, J. B. 2001. Is the resource-based "view" a useful perspective for strategic management research? Yes. Academy of Management Review 26: 41-56.

Baum, J. R., E. A. Locke, and K. G. Smith. 2001. A multidimensional model of venture growth. Academy of Management Journal 44: 292-303.

Beatty, R. P., and E. J. Zajac. 1994. Managerial incentives, monitoring, and risk bearing: A study of executive compensation, ownership and board structure in initial public offerings. Administrative Science Quarterly 39: 313-335.

Bento, A. M., and L. F. White. 2001. Organization form, performance and information costs in small businesses. Journal of Applied Business Research 17(4), 41-61.

Bhide, A. 1992. Bootstrap finance: The art of start-ups. Harvard Business Review 70(6): 109-117.

Birley, S., and S. Stockley. 2000. Entrepreneurial teams and venture growth. In D. L. Sexton and H. Landstrom, eds., The Blackwell Handbook of Entrepreneurship. Oxford: Blackwell, 287-307.

Block, Z., and O. A. Ornati. 1987. Compensating corporate venture managers. Journal of Business Venturing 2: 41-51.

Bloodgood, J. M., H. J. Sapienza, and J. G. Almeida. 1996. The internationalization of new high-potential U.S. ventures: Antecedents and outcomes. Entrepreneurship Theory and Practice 20: 61-76.

Boeker, W. 1989. Strategic change: The effects of founding and history. Academy of Management Journal 32: 489-515.

Boyd, B. K., and A. Salamin. 2001. Strategic reward systems: A contingency model of pay system design. Strategic Management Journal 22: 777-792.

Brophy, D. J. 1997. Financing the growth of entrepreneurial firms. In D. L. Sexton and R. W. Smilor, eds., Entrepreneurship 2000. Chicago: Upstart Publishing, 5-27.

Brush, C. G. and R. Chaganti. 1998. Businesses without glamour? An analysis of resources on performance by size and age in small service and retail firms. Journal of Business Venturing 14: 233-257.

Brush, C. G., P. G. Greene, and M. M. Hart. 2001. From initial idea to unique advantage: The entrepreneurial challenge of constructing a resource base. Academy of Management Executive 15(1): 64-78.

Brush, C. G., and P. A. VanderWerf. 1992. A comparison of methods and sources for obtaining estimates of new venture performance. Journal of Business Venturing 7: 157-170.

Burgel, O., A. Fier, G. Licht, and G. C. Murray. 2000. The effect of internationalization on the rate of growth of high-tech startups: Evidence for UK and Germany. Frontiers of Entrepreneurship Research. Wellesley, MA: Babson College, 425-438.

Cable, D. M., and S. Shane. 1997. A prisoner's dilemma approach to entrepreneur-venture capitalist relations. Academy of Management Review 22: 142-176.

Case, J. 1995. Open book management. New York: Harper Business.

Castanias, R. P., and C. E. Helfat. 2001. The managerial rents model: Theory and empirical analysis. Journal of Management 27: 661-78.

Certo, S. T., C. M. Daily, A. A., Cannella, Jr., and D. R. Dalton. 2003. Giving money to get money: How CEO stock options and CEO equity enhance IPO valuations. Academy of Management Journal 46: 643-653.

Chandler, G. N., and S. H. Hanks. 1994. Resource-based capabilities, strategy, and new venture performance. Journal of Business Venturing 9: 331-349.

Chandler, G. N., and G. M. McEvoy. 2000. Human resource management, TQM, and firm performance in small and medium-size enterprises. Entrepreneurship Theory and Practice 25(1): 43-57.

Cooper, A. C., and A. Bruno. 1977. Success among high-technology firms. Business Horizons 20: 16-22.

Cooper, A. C., and C. M. Daily. 1997. Entrepreneurial teams. In D. L. Sexton and R. W. Smilor, eds., Entrepreneurship 2000. Chicago: Upstart Publishing, 127-150.

Cooper, A., and T. Folta. 2000. Entrepreneurship and high-technology clusters. In D. L. Sexton and H. Landstrom, eds., The Blackwell Handbook of Entrepreneurship. Oxford: Blackwell, 348-367.

Cox, L. W., M. D. Ensley, and S. M. Camp. 2003. The “Resource Balance Proposition”: Balancing Resource Allocations and Firm Growth. In G. Libecap, ed., Advances in the Study of Entrepreneurship, Innovation, and Economic Growth. London: JAI Press, 47-68.

Dalton, D. R., C. M. Daily, S. T. Certo, and R. Roengpitya. 2003. Meta-analysis of financial performance and equity: Fusion or confusion? Academy of Management Journal 46, 13-26. 
Davidsson, P. 1991. Continued entrepreneurship: Ability, need, and opportunity as determinants of small firm growth. Journal of Business Venturing 6: 405-429.

Davidsson, P., and J. Wiklund. 2000. Conceptual and empirical challenges in the study of firm growth. In D. L. Sexton and H. Landstrom, eds., The Blackwell Handbook of Entrepreneurship. Oxford: Blackwell, 26-44.

Deephouse, D. L. 1996. Does isomorphism legitimate? Academy of Management Journal 39, 1024-1039.

Delaney, J. T., and M. A. Huselid. 1996. The impact of human resource management practices on perceptions of organizational performance. Academy of Management Journal 39: 949-969.

Dowling, M. J., and J. E. McGee. 1994. Business and technology strategies and new venture performance: a study of the telecommunications equipment industry. Management Science 40: 1663-1677.

Durand, R., and V. Vargas. 2003. Ownership, organization, and private firms' efficient use of resources. Strategic Management Journal 24: 667-675.

Eisenhardt, K. M., and C. B. Schoonhoven. 1990. Organizational growth: Linking founding team, strategy, environment, and growth among U.S. semiconductor ventures, 1978-1988. Administrative Science Quarterly 35: 504-529.

Fama, E. F., and M. C. Jensen. 1983. Separation of ownership and control. Journal of Law and Economics 26: 301-325.

Fombrun, C. J., and S. Wally. 1989. Structuring small firms for rapid growth. Journal of Business Venturing 4: 107-22.

Grant, R. M. 1996. Prospering in dynamically-competitive environments: Organizational capability as knowledge integration. Organizational Science 7: 375-387.

Greenberger, D. B., and D. L. Sexton. 1988. An interactive model of new venture initiation. Journal of Small Business Management 26(3): 1-7.

Greiner, L. 1998. Evolution and revolution as organizations grow. Harvard Business Review 76(3): 55-65.

Hambrick, D. C., and L. M. Crozier. 1985. Stumblers and stars in the management of rapid growth. Journal of Business Venturing 1: 31-45.

Heneman, R. L., J. W. Tansky, and S. M. Camp. 2000. Human resource management practices in small and medium-sized enterprises: Unanswered questions and future research perspectives. Entrepreneurship Theory and Practice 25(1): 11-26.

Himmelberg, C. P., R. G. Hubbard, and D. Palia. 1999. Understanding the determinants of managerial ownership and the link between ownership and performance. Journal of Financial Economics 53: 353-384.

Hitt, M. A., R. D. Ireland, and R. E. Hoskisson. 2001. Strategic Management: Competitiveness and Globalization, 4th ed. Cincinnati, OH: South-Western College Publishing.

Hoskisson, R. E., M. A. Hitt, R. A. Johnson, and W. Grossman. 2002. Conflicting voices: The effects of institutional ownership heterogeneity and internal governance on corporate innovation strategies. Academy of Management Journal 45: 697-716.

Hulse, D., and T. Pope. 1996. The effect of income taxes on the preference of organizational forms for small business in the United States. Journal of Small Business Management 34(1): 24-35.

Ireland, R. D., D. F. Kuratko, and J. S. Hornsby. 2001. Improving firm performance through entrepreneurial actions: Accordia's corporate entrepreneurship strategy. Academy of Management Executive 15(4): 60-71.

Jensen, M., and W. Meckling. 1976. Theory of the firm: Managerial behavior, agency costs, and ownership structure. Journal of Financial Economics 3: 305-360.

Katz, J. A., H. E. Aldrich, T. M. Welbourne, and P. M. Williams. 2000. Special issue on human resource management and the SME: Toward a new synthesis. Entrepreneurship Theory and Practice 25(1): 7-10.

Kambil, A., E. D. Eselius, and K. A. Monteiro. 2000. Fast venturing: The quick way to start web businesses. Sloan Management Review 41(4): 55-67.

Kazanjian, R. K., and R. Drazin. 1990. A stage-continent model of design and growth for technology-based new ventures. Journal of Business Venturing 5: 137-150.

Keasey, K., and R. Watson. 1993. Small Firm Management: Ownership, Finance, and Performance. Oxford, UK: Blackwell.

Kelly, P., and Hay, M. 2000. The private investor-entrepreneur contractual relationship: Understanding the influence of context." In Frontiers of Entrepreneurship Research. Wellesley, MA: Babson College, 258-271.

Landstrom, H., and D. L. Sexton. 2000. Remaining issues and suggestions for further research. In D. L. Sexton and H. Landstrom, eds., The Blackwell Handbook of Entrepreneurship. Oxford: Blackwell, 435-443.

Lounsbury, M., and M. A. Glynn. 2001. Cultural entrepreneurship: Stories, legitimacy, and the acquisition of resources. Strategic Management Journal 22, 545-564.

MacMillan, I., R. Siegel, and P. SubbaNarasimha. 1985. Criteria used by venture capitalists to evaluate new venture proposals. Journal of Business Venturing 1: 119-128. 
Manigart, S., and H. Sapienza. 2000. Venture Capital and Growth. In D. L. Sexton and H. Landstrom, eds., The Blackwell Handbook of Entrepreneurship. Oxford: Blackwell, 240-258.

Markman, G. D., D. B. Balkin, and L. Schjoedt. 2001. Governing the innovation process in entrepreneurial firms. Journal of High Technology Management Research 12, 273-293.

Mason, C., and R. Hamilton. 2000. Informal venture capital and the financing of emergent growth businesses. In D. L. Sexton and H. Landstrom, eds., The Blackwell Handbook of Entrepreneurship. Oxford: Blackwell, 221-239.

Mizik, N., and R. Jacobson. 2003. Trading off between value creation and value appropriation: The financial implications of shifts in strategic emphasis. Journal of Marketing 67: 63-76.

Moran, S., and P. Ghoshal. 1996. Bad for practice: A critique of transaction cost theory. Academy of Management Review 21: $13-47$.

Rajagopalan, N. 1997. Strategic orientations, incentive plan adoptions, and firm performance: Evidence from electric utility firms. Strategic Management Journal 18: 761-785.

Reynolds, P. D. 1987. New firms: Societal contribution versus potential. Journal of Business Venturing 2: 231-246.

Robinson, K. C. 1999. An examination of the influence of industry structure on eight alternative measures of new venture performance for high potential independent new ventures. Journal of Business Venturing 14: 165-187.

Robinson, K. C. and P. P. McDougall. 1998. The impact of alternative operationalizations of industry structural elements on measures of performance for entrepreneurial manufacturing ventures. Strategic Management Journal 19: 1079-1100.

Sexton, D. L., and N. Bowman-Upton. 1991. Entrepreneurship: Creativity and Growth. New York: Macmillan.

Siegel, R., E. Siegel, and I. MacMillan. 1993. Characteristics distinguishing high growth ventures. Journal of Business Venturing 8: 169-180.

Smith, C., and R. Watts. 1992. The investment opportunity set and corporate financing dividend and compensation policies. Journal of Financial Economics 19: 263-292.

Stroh, J. B. 1996. Agency theory and variable pay compensation strategies. Academy of Management Journal 39: 751-767.

Sykes, H. B. 1992. Incentive compensation for corporate venture personnel. Journal of Business Venturing 7: 253-265.

Vesper, K. H. 1990. New venture strategies. Englewood Cliffs, NJ: Prentice-Hall.

Vroom, V. H. 1964. Work and Motivation. New York: Wiley.

Welbourne, T. M., and A. O. Andrews. 1996. Predicting the performance of initial public offerings: Should human resource management be in the equation? Academy of Management Journal 39: 891-919.

Williamson, O. E. 1993. Opportunism and its critics. Managerial and Decision Economics 14: 97-107.

Zahra, S. A., D. O. Neubaum, M. Huse. 2000. Entrepreneurship in medium-size companies: Exploring the effects of ownership and governance systems. Journal of Management 26: 947-976. 


\section{MEjE}

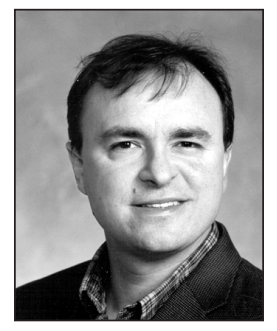

\section{About the Authors}

J. B. Arbaugh (arbaugh@uwosh.edu) is the Curwood Inc. Endowed Professor at the University of Wisconsin Oshkosh. His research in online learning has been awarded Academy of Management Division Best Paper Awards in 2001, 2002, and 2003. His other research interests are in international entrepreneurship, management of rapidly growing firms, and the intersection between spirituality and strategic management research. Some of his recent and forthcoming publications include articles in Academy of Management Learning and Education, Management Learning, Journal of High-Technology Management Research, Business Communication Quarterly, Journal of Management Education, and Journal of Management, Spirituality, and Religion.

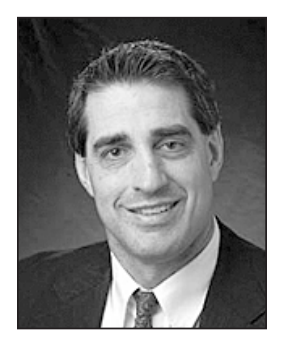

LARRY W. Cox (lcox@bus.wisc.edu) is the director of the Weinert Center for Entrepreneurship at the University of Wisconsin-Madison. He received his Ph.D. from the University of Nebraska. While earning his advanced degrees, Dr. Cox served as the director of the Nebraska Business Development Center and consulted hundreds of would-be entrepreneurs. His personal research interests include the dynamics of high-growth firms, impact of entrepreneurship education, and cognitive processes of entrepreneurs.

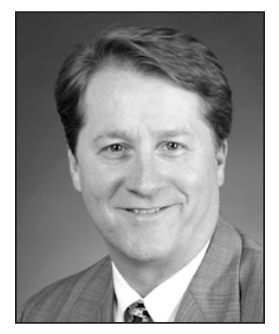

S. Michael CAmp (camp_1@cob.osu.edu ) is the academic director for the Center for Entrepreneurship at The Ohio State University and founder and president of Advanced Research Technologies, LLC. He received his Ph.D from The Ohio State University. Previously, Dr. Camp was the vice-president of research for the Ewing Marion Kauffman Foundation. In addition to publishing numerous books and articles, Dr. Camp was a guest editor of recent issues of the Academy of Management Executive and Strategic Management Journal related to the role of entrepreneurship in wealth creation. 